\title{
Perancangan Federal Enterprise Architecture Framework Pengelolaan Surat Pada Dinas Perhubungan Kabupaten Sukabumi
}

\author{
Salsa Tini Kareksi ${ }^{1}$, Sudin Saepudin ${ }^{2}$ \\ 1,2 Program Studi Sistem Informasi, Universitas Nusa Putra, Jawa Barat, Indonesia \\ Email: salsa.tini_si17@nusaputra.ac.id
}

\begin{abstract}
The Sukabumi Regency Transportation Office has several fields, one of which is the Head of the General and Civil Service Sub-section which bas the function of collecting and processing data. This function, of course, is mostly carried out by the letter archiving department because this section is the most important part or can be called the heart of the Sukabumi Regency Transportation Service. Where the section regulates the management of incoming letters, outgoing letters, and mail reports. Mail management activities still use agenda books, disposition cards and Microsoft Office so that mail management activities are still not optimal. From the letter management activities at the Sukabumi Regency Transportation Office, several problems were found, namely there was a loss of incoming mail data in 2019 reaching 50\% while errors in letter data collection occurred in outgoing mail data reaching 10-40\% so that it could affect the reporting of the number of letters. The Transportation Agency of Sukabumi Regency must realize Enterprise Architecture to be able to regulate and supervise the management of letters. With this in mind, the researcher will make a "Design of the Federal Enterprise Architecture Framework on Mail Management at the Sukabumi Regency Transportation Service". This will be a solution to these problems, this research will produce a framework (blueprint) in the form of business architecture, data architecture, application architecture, and technology architecture.
\end{abstract}

Keywords: Sukabumi District Transportation Office, Mail Management, Enterprise Architecture, Federal Enterprise Architecture Framework.

\begin{abstract}
ABSTRAK
Dinas Perhubungan Kabupaten Sukabumi mempunyai beberapa bidang salah satunya bidang Kasubag Umum dan Kepegawaian yang mempunyai fungsi pengumpulan dan pengolahan data. Fungsi tersebut tentunya banyak dikerjakan oleh bagian pengarsipan surat karena bagian tersebut merupakan bagian yang paling penting atau bisa disebut sebagai jantung dari Dinas Perhubungan Kabupaten Sukabumi. Dimana bagian tersebut mengatur pengelolaan dalam surat masuk, surat keluar, dan laporan surat. Kegiatan pengelolaan surat masih menggunakan buku agenda, kartu disposisi dan Microsoft Office sehingga kegiatan pengelolaan surat terlihat masih belum optimal. Dari kegiatan pengelolaan surat di Dinas Perhubungan Kabupaten Sukabumi ditemukan beberapa permasalahan yaitu terjadi kehilangan data surat masuk tahun 2019 mencapai 50\% sedangkan kesalahan dalam pendataan surat terjadi pada data surat keluar mencapai 1040\% sehingga dapat berpengaruh terhadap pembuatan laporan jumlah surat. Dinas Perhubungan Kabupaten Sukabumi harus mewujudkan Enterprise Architecture untuk dapat mengatur dan mengawasi dalam pengelolaan surat. Dengan adanya hal tersebut, maka peneliti akan membuat "Perancangan Federal Enterprise Architecture Framework Pada Pengelolaan Surat Di Dinas Perhubungan Kabupaten Sukabumi”. Hal ini akan menjadi solusi dari permasalahan tersebut. Penelitian ini akan menghasilkan kerangka kerja (blueprint) yang berupa business architecture, data architecture, application architecture, dan technology architecture.
\end{abstract}

Kata kunci: Dinas Perhubungan Kabupaten Sukabumi, Pengelolaan Surat, Enterprise Architecture, Federal Enterprise Architecture Framework

\section{Pendahuluan}

Teknologi informasi berupa teknologi yang digunakan untuk menangani informasi, menghitung, mendapatkan, menyusun, menyimpan, mengontrol informasi dengan berbagai cara untuk menghasilkan data yang berkualitas, khususnya data yang penting dan tepat yang digunakan 
untuk individu, bisnis, dan pemerintahan yang merupakan teknik data untuk pengambilan keputusan.[1] Menurut Jogiyanto (2005) Sistem Informasi adalah : "Suatu sistem didalam suatu organisasi yang mempertemukan kebutuhan pengolahan transaksi harian, mendukung operasi, bersifat manajerial dan kegiatan strategi dari suatu organisasi dan menyediakan pihak luar tertentu dengan laporan-laporan yang diperlukan"[2]. Enterprise Architecture adalah kerangka bisnis dengan lingkungan bisnis yang seharusnya dan bahkan dapat menjadi rencana untuk mengelola dan bekerja setiap komponen bisnis, untuk ilustrasi, kebijakan, operasi, kerangka kerja dan data.[3]

Dinas Perhubungan Kabupaten Sukabumi mempunyai susunan oganisasi yang terdiri dari kepala dinas dan sekretariat. Sekretariat membawahi beberapa bagian salah satunya bagian Kasubag Umum dan Kepegawaian. Berdasarkan SOTK pada "peraturan Bupati Sukabumi Nomor 68 tahun 2016 tentang struktur organisasi dan tata kerja Dinas Perhubungan”. Kasubag Umum dan Kepegawaian mempunyai salah satu fungsi yaitu pengumpulan dan pengolahan data. kegiatan pengumpulan dan pengelolaan data tentunya banyak dilakukan pada bagian pengarsipan surat karena bagian tersebut merupakan bagian yang paling penting atau bisa disebut sebagai jantung dari Dinas Perhubungan Kabupaten Sukabumi karena bagian tersebut tempat mengelola surat masuk, surat keluar, dan laporan surat yang berguna untuk mempertanggung jawabkan dari setiap agenda kegiatan yang memanfaatkan media surat sebagai bahan untuk kerjasama antara perseorangan atau dengan instansi lainnya. Kegiatan pengelolaan surat di Dinas Perhubungan Kabupaten Sukabumi masih menggunakan buku agenda dan Microsoft Office serta dalam pengarahan suratnya masih menggunakan kartu disposisi. Apabila dilihat dari kegiatan pengelolaan surat belum adanya teknologi informasi yang sangat efektif untuk membantu dalam proses kegiatan pengelolaan surat tersebut, serta belum adanya pengelompokan data mengenai data surat. Permasalahan lebih jelas kami tampilkan pada Gambar 1 dan Gambar 2.

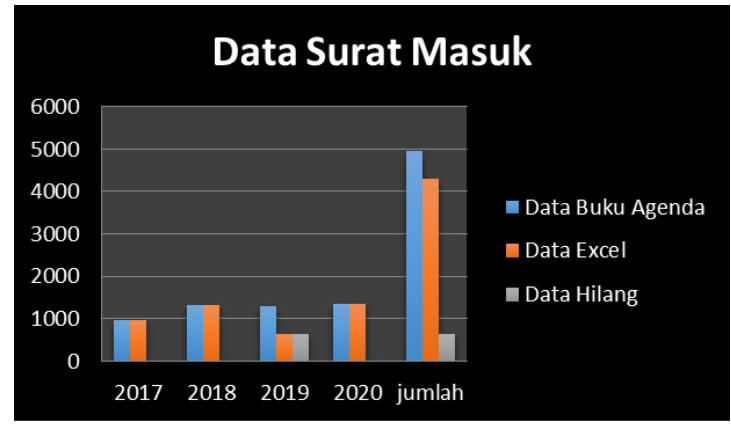

Gambar 1. Data Surat Masuk

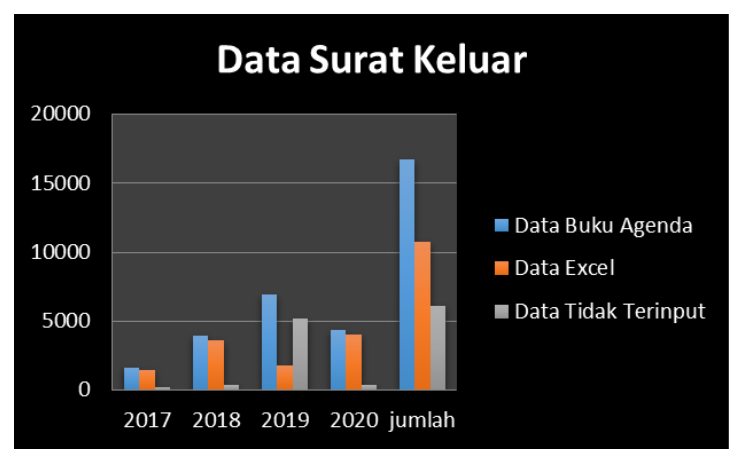

Gambar 2. Data Surat Keluar

Berdasarkan grafik di atas maka bisa dilihat adanya ketidaksesuaian pada grafik data surat masuk disebabkan karena telah terjadinya kehilangan data surat masuk pada tahun 2019 secara garis 
besar mencapai 50\% sedangkan permasalahan selanjutnya terjadi pada grafik data surat keluar yang disebabkan terjadinya kesalahan dalam pendataan surat keluar yang mencapai $10-40 \%$ sehingga hal tersebut bisa berpengaruh terhadap pembuatan laporan surat. Oleh karena itu, maka Dinas Perhubungan Kabupaten sukabumi perlu mewujudkan Enterprise Architecture yang dapat digunakan untuk mengatur dan mengawasi pengelolaan surat. Berdasarkan kondisi tersebut peneliti membuat penelitian tentang "Perancangan Federal Enterprise Architecture Framework Pada Pengelolaan Surat Di Dinas Perhubungan Kabupaten Sukabumi" sebagai solusi dari permasalahan tersebut. Penelitian ini akan menghasilkan kerangka kerja (blueprint) yang berupa business architecture, data architecture, application architecture, dan technology architecture.

\section{Kerangka Teoritis dan Pengembangan Hipotesis Penelitian Terkait}

Penelitian terkait pertama diperoleh dari jurnal "Perancangan Sistem Informasi Pengelolaan Surat Masuk Surat Keluar Dan SPPD Di kelurahan Jatijajar". Metode penelitian yang digunakan yaitu metode Grounded Research[4].

Penelitian terkait kedua diperoleh dari jurnal "Perancangan Blueprint Sistem Informasi Manajemen Arsip Berbasis Web dengan TOGAF ADM (Studi Kasus : Sekretariat IBI Kota Boyolali)". Dalam penelitian tersebut peneliti menggunakan Togaf ADM sebagai framework dalam perancangan arsitektur. Hasil penelitian tersebut berupa blueprint arsitektur sistem informasi Bidan Indonesia (IBI) boyolali yang akan menunjang proses Bidan Indonesia (IBI) boyolali secara menyeluruh dan menyelesaikan permasalahan sistem informasi yang masih belum terintegrasi. [5]

Penelitian terkait ketiga diperoleh dari jurnal "Perancangan Sistem Informasi Pengarsipan Dan Disposisi Surat Berbasis Web Dengan Menggunakan framework Codeigniter". Metode penelitian yang digunakan yaitu SDLC (System Development Life Cycle) yang menghasilkan sistem informasi yang dibuat dengan pemrograman web yaitu Object Oriented Programming dengan Framework Codeigniter. [6]

\section{Definisi Enterprise Architecture}

Enterprise Architecture (EA) dapat didefinisikan sebagai sebuah blueprint (Minoli, 2008:35) yang menggambarkan bagaimana semua komponen teknologi informasi dan eksekutif bekerja sama sebagai satu kesatuan dan memberikan gambaran yang jelas tentang hubungan antara teknologi informasi saat ini dan yang diharapkan yang diukur oleh enterprise. Enterprise Architecture (EA) harus memberikan sistem yang memungkinkan asosiasi untuk membantu statusnya saat ini dan keadaan yang sekarang juga bertindak sebagai roadmap menuju lingkungan yang ditargetkan[7].

\section{Definisi Metode FEAF (Federal Enterprise Architecture Framework)}

Pada bulan September 1999, Federal CIO Council mendistribusikan Kerangka Kerja Federal Enterprise Architecture Framework Version 1.1 untuk membuat EA di dalam Kantor Pemerintah mana pun atau untuk kerangka kerja yang melampaui banyak batas antar-lembaga. FEAF memberikan standar untuk mengembangkan penggambaran desain dari rentang prioritas tinggi. Ini memberikan arahan dalam menggambarkan desain untuk segmen fungsional multi-organisasi dari pemerintahan federal. Secara kolektif membentuk Enterprise Architecture Federal[8]. 


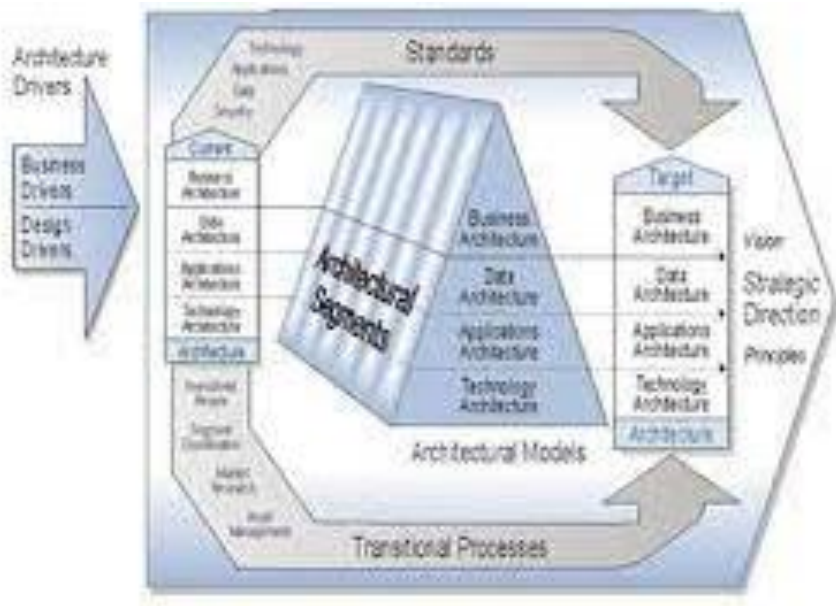

Gambar 3. Struktur Komponen Federal Enterprise Architecture Framework

\section{Metode}

\section{Tahap Penelitian}

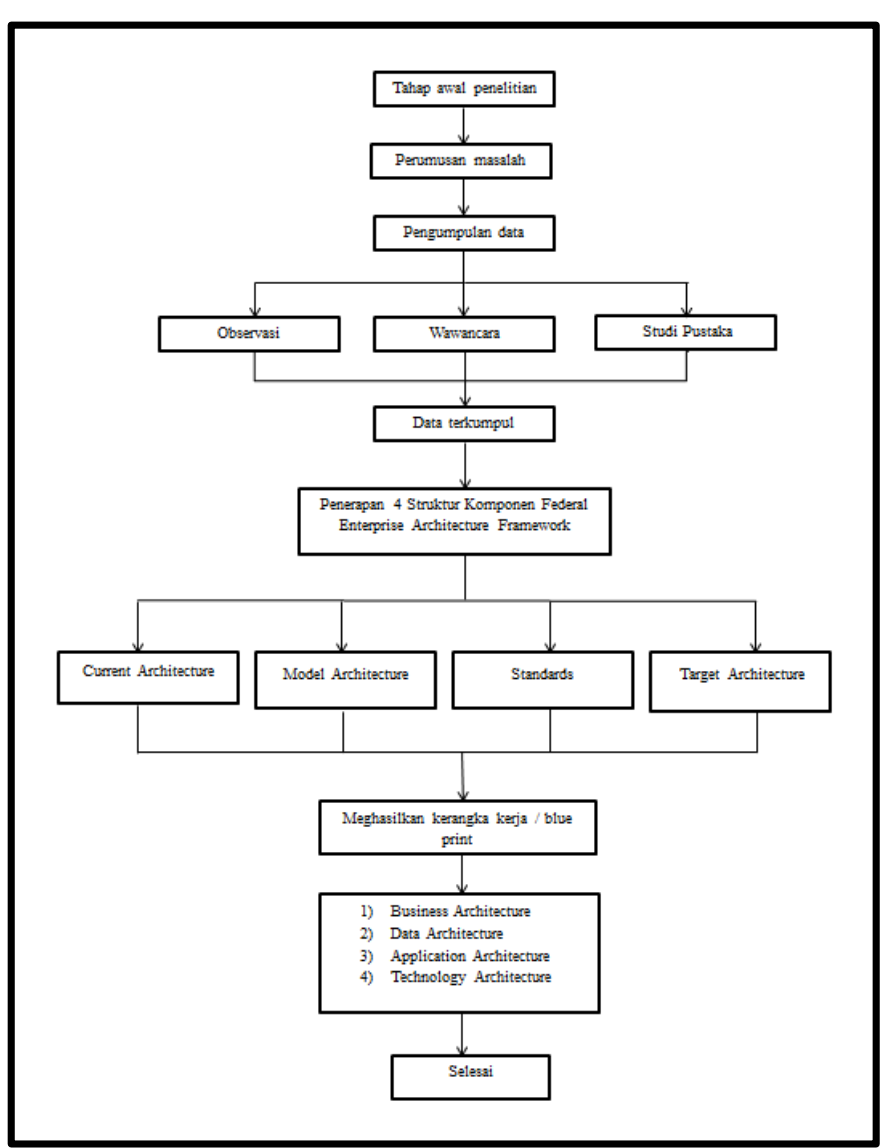

Gambar 4. Tahapan-tahapan penelitian

\section{Pengumpulan Data}

Arikunto menjelaskan bahwa: "Observasi dalam pengertian psikologi observasi atau bisa dikatakan sebagai pengamat, meliputi kegiatan pemutusan suatu perhatian terhadap suatu objek dengan menggunakan seluruh alat indra[9]." Observasi dilakukan secara langsung pada Dinas Perhubungan Kabupaten Sukabumi. Wawancara dilakukan untuk mengetahui jumlah data dan 
upaya memperoleh informasi yang akurat dan sesuai sumber informasi[10]. Wawancara dilakukan dengan narasumber terkait dan mengajukan pertanyaan tentang pengelolaan surat-menyurat di Dinas Perhubungan Kabupaten Sukabumi. Studi pustaka dilakukan dengan membaca secara teliti berdasarkan tulisan dari buku-buku, buku harian dan makalah yang berencana untuk memunculkan konsep-konsep hipotesis yang ada di sekitar masalah untuk ditanyakan dan mencari sumber informasi di web dan perpustakaan[11]. Dalam penelitian ini peneliti mengumpulkan jurnal-jurnal terkait dengan penelitian dengan memanfaatkan media internet untuk mencari sumber juga mengumpulkan referensi dan buku-buku di perpustakaan Universitas Nusa Putra sesuai dengan penelitian.

\section{Langkah-langkah Penelitian}

Langkah-langkah pada penelitian ini akan digunakan untuk merancang enterprise architecture menggunakan metode federal enterprise architecture framework sesuai dengan struktur komponen yang dimiliki oleh FEAF. Penelitian ini hanya menggunakan 4 struktur komponen FEAF yang diperlukan sesuai dengan kebutuhan instansi. Struktur komponen FEAF yang akan digunakan yaitu Current Architecture, Model Architecture, Target Architecture dan Standards.

\section{Hasil dan Pembahasan}

Komponen Current Architecture, Pada struktur komponen FEAF ini menjelaskan kondisi yang sedang berjalan dalam kegiatan pengelolaan surat yang ada di Dinas Perhubungan Kabupaten Sukabumi. Kondisi yang sedang berjalan saat ini dapat dilihat dari beberapa aspek yaitu :

Business Architecture, yang saat ini berjalan pada kegiatan pengelolaan surat di gambarkan pada use case diagram berjalan surat masuk dan use case diagram surat keluar.

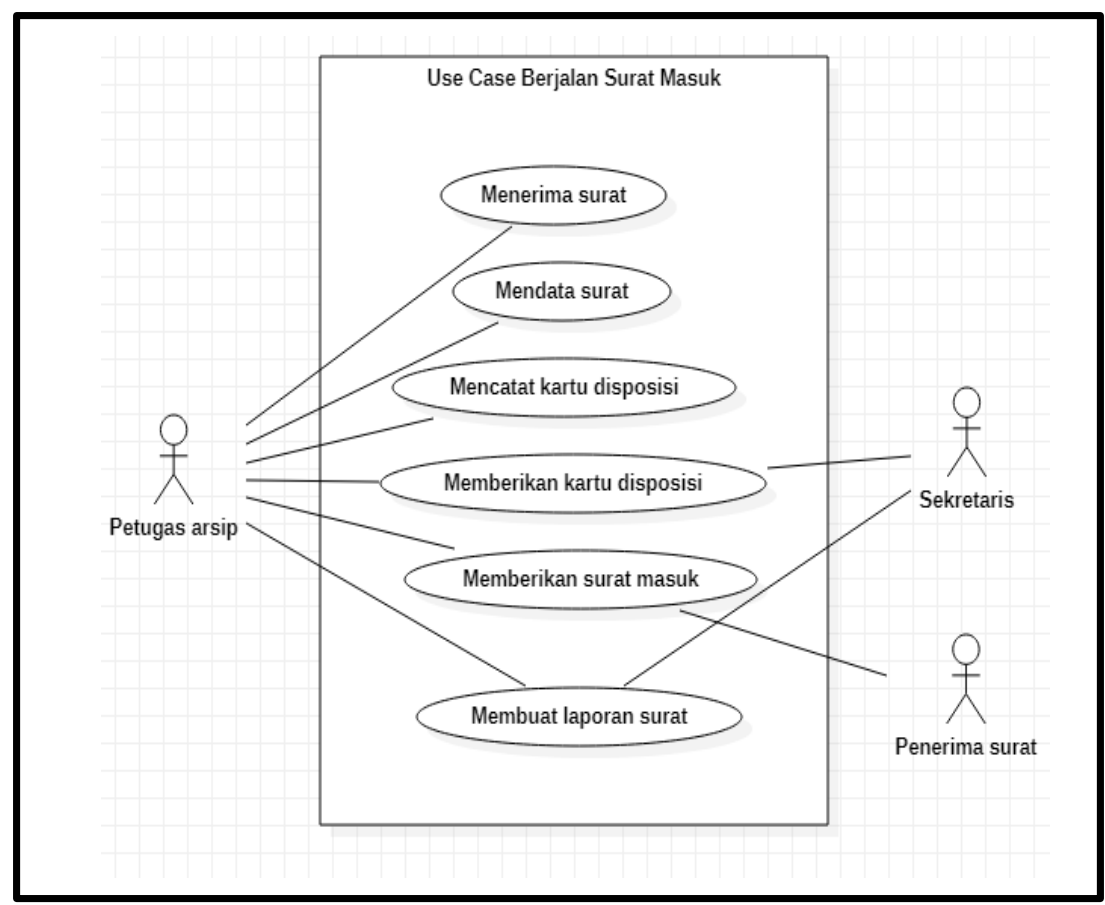

Gambar 5.Use case berjalan surat masuk 


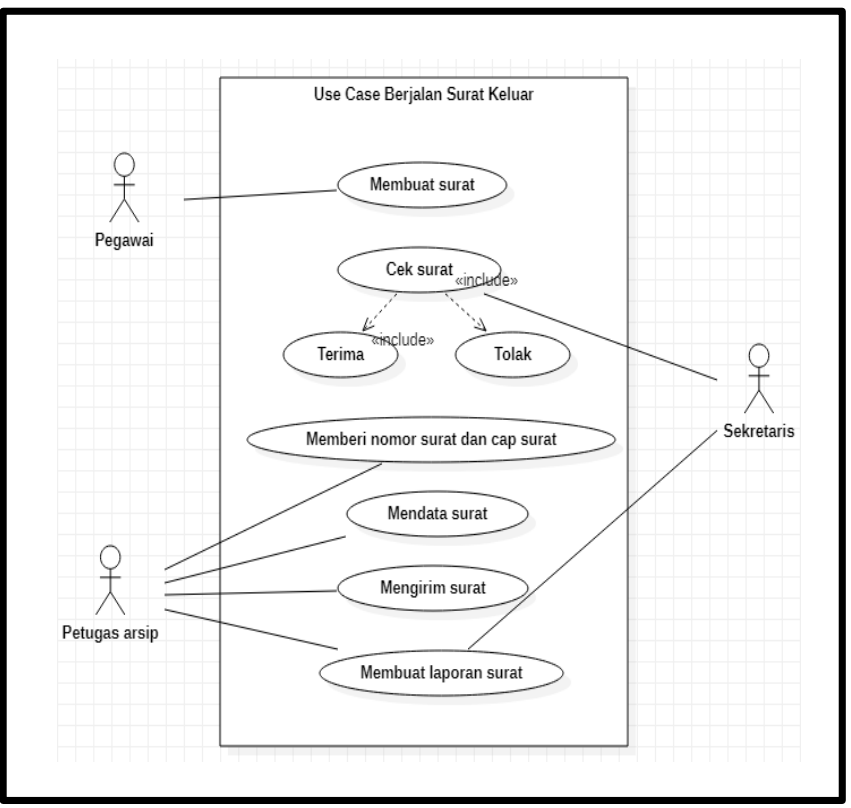

Gambar 6. Use case berjalan surat keluar

Data Architecture, data yang diperoleh dari aktivitas pengelolaan surat yaitu :

- Data surat masuk, data ini diperoleh dari hasil pencatatan formulir kartu kendali naskah dinas masuk berwarna putih, hijau dan merah serta surat masuk yang tercatat dibuku agenda dan yang terisi di kartu disposisi.

- Data surat keluar, data ini diperoleh dari hasil pencatatan formulir kartu kendali naskah dinas keluar berwarna merah, putih, dan kuning.

- Data laporan surat, dihasilkan dari data surat masuk dan data surat keluar yang sudah rekapitulasi.

\section{Application Architecture}

Aplikasi arsitektur yang mendukung dalam kegiatan pengelolaan surat saat ini hanya memanfaat kan Microsoft Office sebagai media penyimpanan data surat kedua selain dari buku agenda.

\section{Technology Architecture}

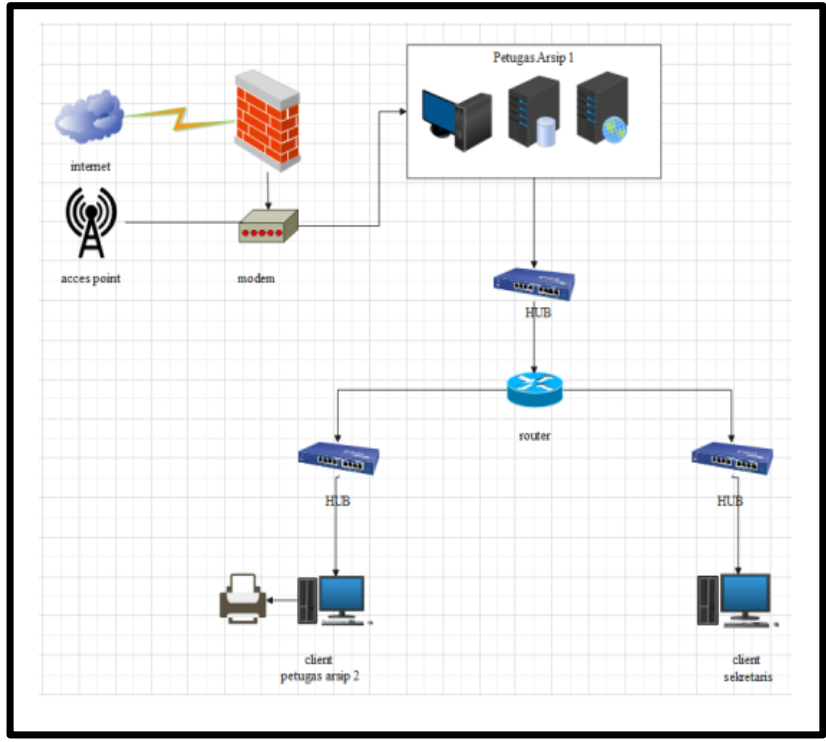

Gambar 7. Arsitektur jaringan saat ini 
Komponen Model Architecture, komponen ini menjelaskan mengenai design yang akan dirancang sesuai dengan kebutuhan pada pengelolaan surat, model architecture ini akan digambarkan melalui use case diagram, activity diagram, class diagram atau database.

Business Architecture, digambarkan dengan menggunakan use case, use case terdiri dari petugas arsip yang menjadi admin dalam pengelolaan surat dan sekretaris sebagai $u$ ser.

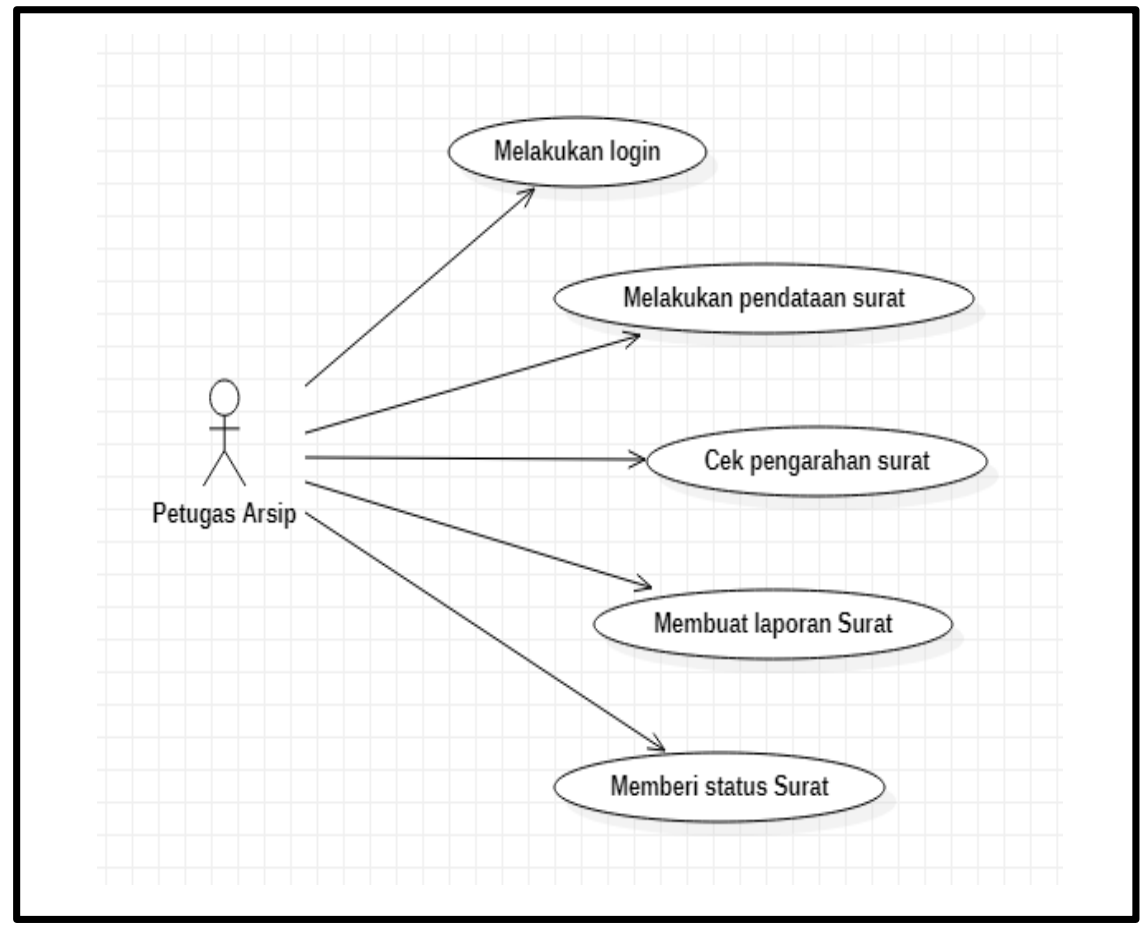

Gambar 8. Use Case Usulan Petugas Arsip

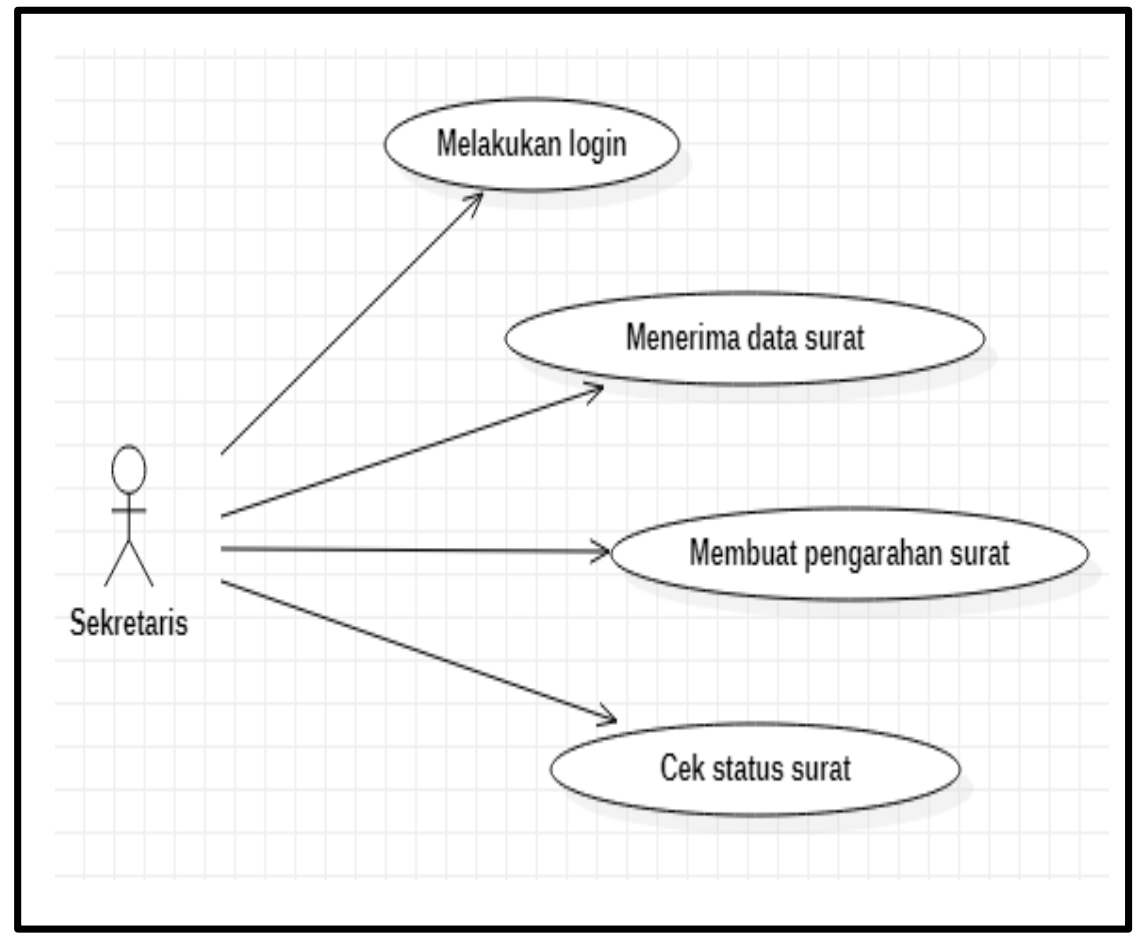

Gambar 9. Use Case Diagram Usulan Sekretaris 
@is The Best : Accounting Information Systems and Information Technology Business Enterprise

ISSN: 2252-9853 (Print) | ISSN: 2656-808X (Online)

Data Architecture, dapat dilihat pada Gambar 10. perancangan database pada pengelolaan surat.

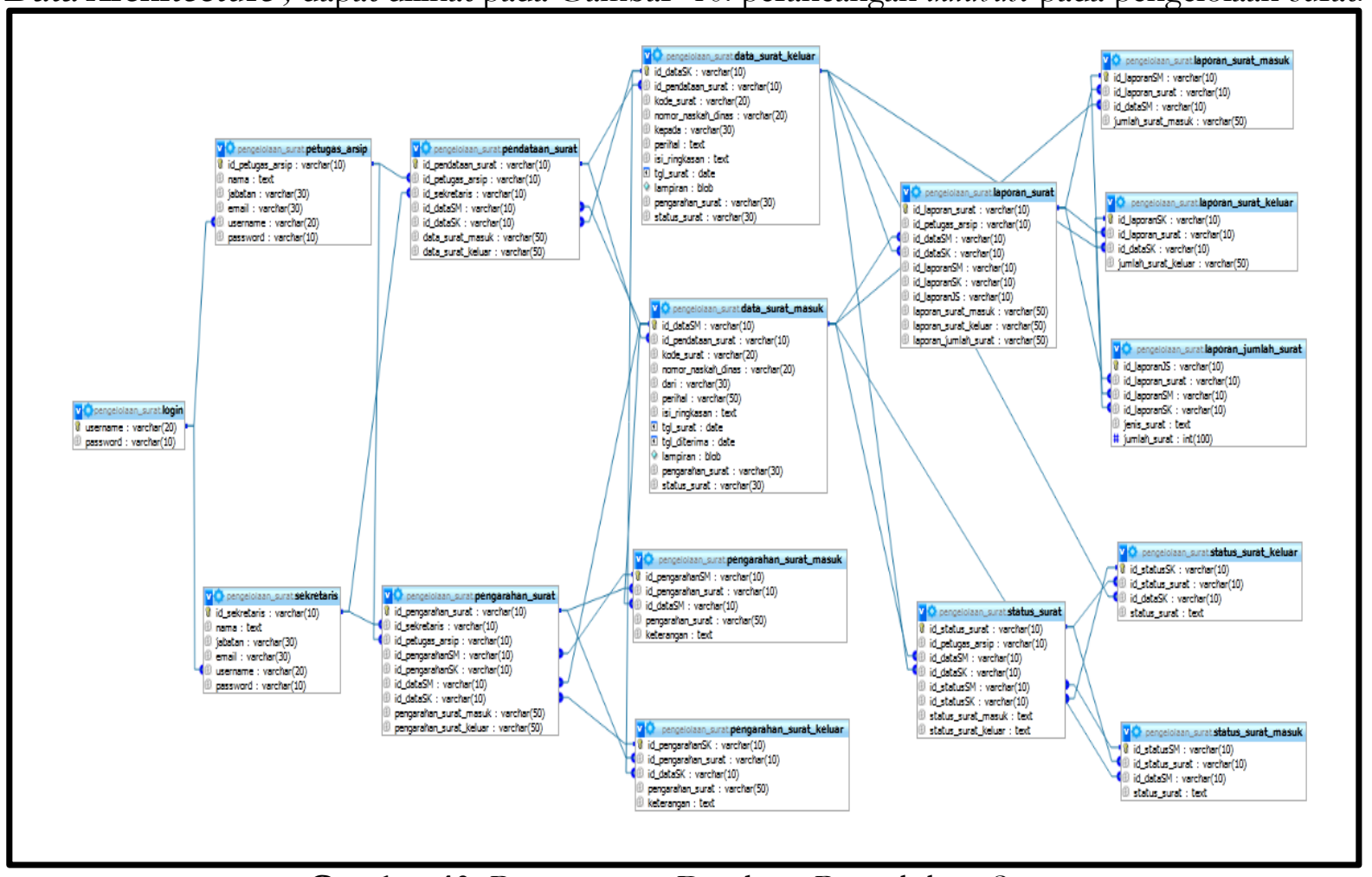

Gambar 10. Perancangan Database Pengelolaan Surat

Application Architecture, yang akan peneliti buat yaitu bias di lihat di Tabel 1. Perancangan Application Architecture.

\begin{tabular}{|l|l|l|}
\hline \multicolumn{1}{|c|}{$\begin{array}{c}\text { Arsitektur } \\
\text { Aplikasi }\end{array}$} & \multicolumn{1}{|c|}{ Fitur } \\
$\begin{array}{l}\text { Sistem } \\
\text { informasi } \\
\text { pengelolaan } \\
\text { surat }\end{array}$ & $\begin{array}{l}\text { Pendataan } \\
\text { surat }\end{array}$ & $\begin{array}{l}\text { Kegiatan pendataan surat pada sistem pengelolaan surat ini } \\
\text { dilakukan oleh petugas arsip yang berperan sebagai admin, } \\
\text { dimana pendataan surat ini akan melakukan input data surat } \\
\text { masuk dan data surat keluar yang nanti nya data surat tersebut } \\
\text { bisa dilihat oleh sekretaris yang berperan sebagai user (pengguna) }\end{array}$ \\
\cline { 2 - 4 } & Pengarahan & $\begin{array}{l}\text { Kegiatan pengarahan surat ini dilakukan oleh sekretaris, setelah } \\
\text { sekretaris menerima data surat masuk maupun data surat keluar, } \\
\text { nantinya akan di buatkan pengarahan surat untuk diberikan } \\
\text { kepada siapa penerima surat masuk dan siapa penanggung jawab } \\
\text { dari surat keluar. Kemudian petugas arsip tinggal mengecek lalu } \\
\text { menyampaikan sesuai pengarahan. }\end{array}$ \\
\cline { 2 - 4 } & $\begin{array}{l}\text { Laporan } \\
\text { surat }\end{array}$ & $\begin{array}{l}\text { Kegiatan laporan surat dibuat oleh petugas arsip yang terdiri dari } \\
\text { jumlah surat masuk dan jumlah surat keluar kemudian hasilnya } \\
\text { akan dilaporkan kepada sekretaris. }\end{array}$ \\
\cline { 2 - 4 } & Status Surat & $\begin{array}{l}\text { Kegiatan pada fitur status surat ini dilakukan oleh petugas arsip, } \\
\text { ketika petugas arsip selesai menyampaikan pengarahan kepada } \\
\text { penerima atau penanggung jawab, maka petugas arsip harus } \\
\text { mengirim status surat apakah sudah dikirim atau diterima. }\end{array}$ \\
\hline
\end{tabular}

Volume 6 Nomor 1 (2021) Hal. 76-90 
Technology Architecture, akan digambarkan pada Gambar 11. Usulan Arsitektur Jaringan.

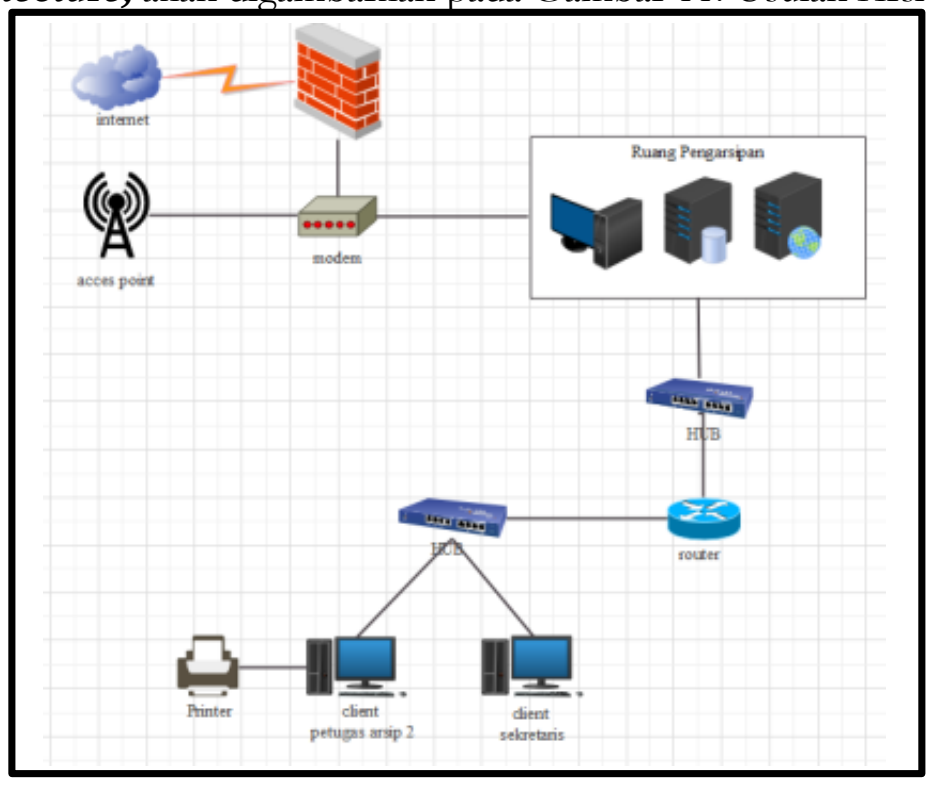

Gambar 11. Usulan Arsitektur Jaringan

Komponen Standards, ini menjelaskan mengenai standar yang diperlukan ketika hasil perancangan pengelolaan surat akan diimplementasikan sehingga akan menghasilkan sebuah sistem yang layak sesuai dengan standar yang dibutuhkan oleh instansi.

Technology, standar teknologi yang dibutuhkan dalam mengimplementasikan hasil dari perancangan pada pengelolaan surat tentunya harus memperhatikan dari segi kelayakan teknologi seperti spesifikasi hardware (perangkat keras) dan spesifikasi software (perangkat lunak) yang akan menunjang berjalannya sistem pengelolaan surat jika akan diimplementasikan.

Application, standar aplikasi yang dirancang tentunya menggambarkan perilaku dalam aktivitas pengelolaan surat, seperti halnya interaksi antara petugas arsip dengan sekretaris yang setiap harinya akan melakukan pertukaran data, pengolahan data, dan penyimpanan data.

Data, standar data pada perancangan pengelolaan surat ini tentunya menjadi hal yang sangat penting sehingga peneliti membuat usulan arsitektur jaringan yang memiliki 2 server yaitu database server dan web server. Dimana database server dapat menyimpan semua data di satu lokasi dengan secara tersusun, kemudian untuk web server dapat menyediakan data sesuai dengan permintaan client yang masuk agar bisa menjamin sistem keamanan data.

Security, untuk sistem keamanan pada perancangan pengelolaan surat ini sangat berfokus pada keamanan database baik dari sisi data yang ada di database maupun meliputi bagian dari database lainnya. Sehingga jika perancangan pengelolaan surat ini diimplementasikan perlu adanya orang yang berperan sebagai administrator database yang betul-betul mempunyai kemampuan dan pengetahuan di bidang database sistem.

Komponen Target Architecture, pada komponen target arsitektur ini akan menghasilkan perancangan yang sesuai dengan kebutuhan yang diperlukan dalam aktivitas pengelolaan surat. Serta menjelaskan bagaimana aktivitas yang dapat dilihat pada activity diagram yang diusulkan.

Business Architecture, kegiatan bisnis arsitektur dapat dilihat dalam aktivitas yang akan disampaikan melalui activity diagram dibawah ini. 
Salsa Tini Kareksi ${ }^{1}$, Sudin Saepudin ${ }^{2}$

@is The Best : Accounting Information Systems and Information Technology Business Enterprise ISSN: 2252-9853 (Print) | ISSN: 2656-808X (Online)

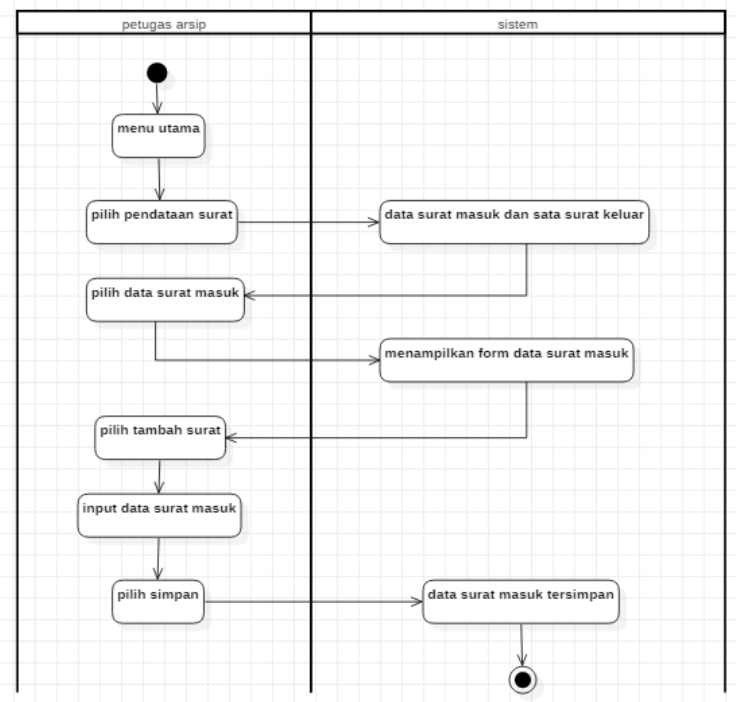

Gambar 12. Diagram Aktivitas Pendataan Surat

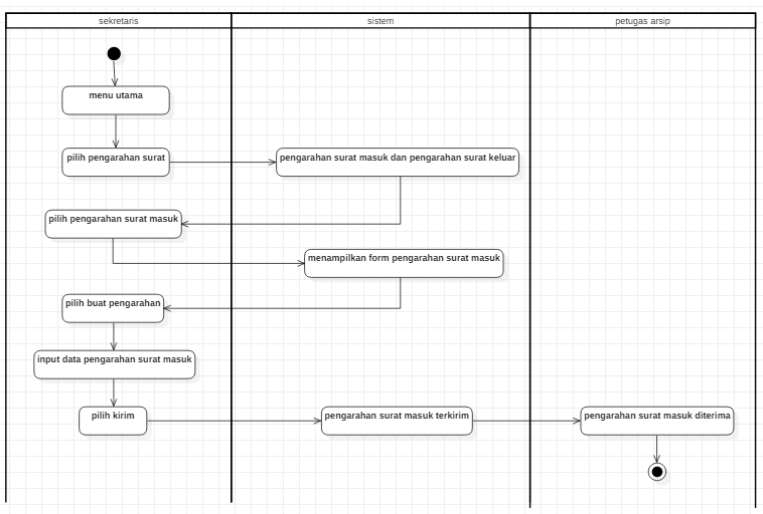

Gambar 13. Diagram Aktivitas Pengarahan Surat

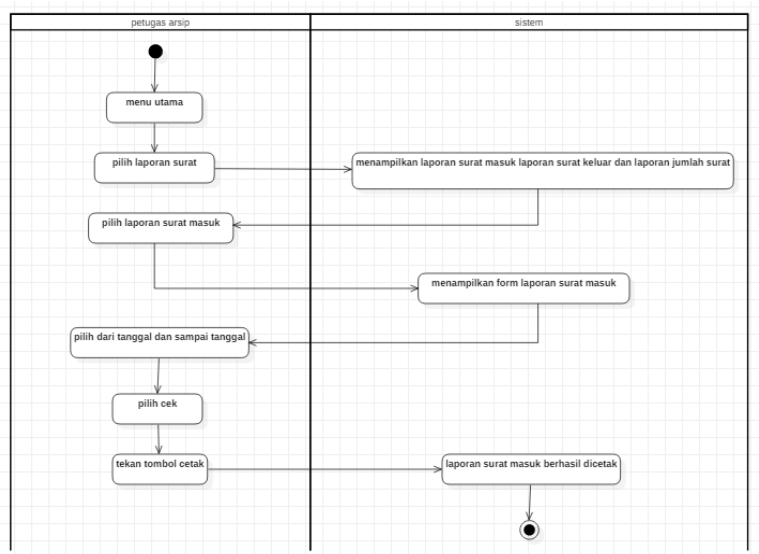

Gambar 14. Diagram Aktivitas Laporan Surat 


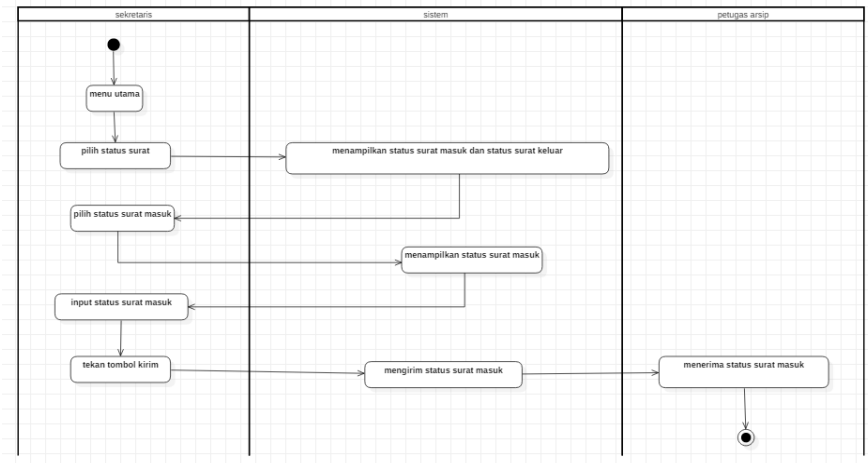

Gambar 15. Diagram Aktivitas Status Surat

Data Architecture, untuk data arsitektur dapat dilihat pada Tabel 2. Proses Create Table Database.

Tabel 2. Proses Create Table Database

\begin{tabular}{|c|c|}
\hline Fitur pada pengelolaan surat & Proses Create Table \\
\hline Login & $\begin{array}{l}\text { CREATE TABLE `pengelolaan_surat``login`('username` } \\
\text { VARCHAR (20) NOT NULL, ’password`VARCHAR (10) } \\
\text { NOT NULL, PRIMARY KEY ('username`)) ENGINE = } \\
\text { InnoDB; }\end{array}$ \\
\hline Petugas_arsip & 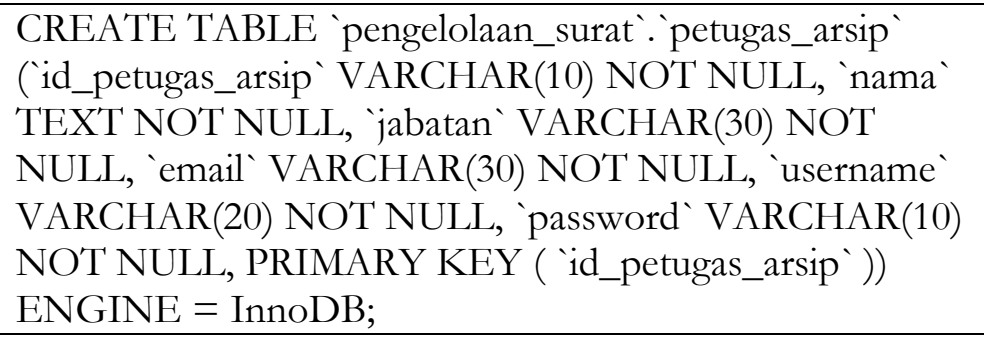 \\
\hline Sekretaris & $\begin{array}{l}\text { CREATE TABLE `pengelolaan_surat``sekretaris` } \\
\text { (`id_sekretaris`VARCHAR(10) NOT NULL, `nama` } \\
\text { TEXT NOT NULL, `jabatan`VARCHAR(30) NOT } \\
\text { NULL, `email`VARCHAR(30) NOT NULL, `username` } \\
\text { VARCHAR(20) NOT NULL, `password `VARCHAR(10) } \\
\text { NOT NULL, PRIMARY KEY ('id_sekretaris`)) ENGINE } \\
=\text { InnoDB }\end{array}$ \\
\hline Pendataan_surat & 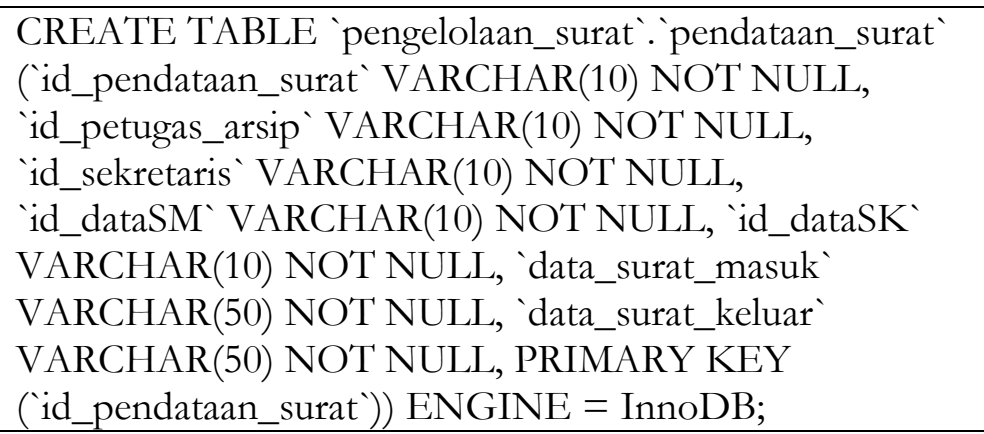 \\
\hline Data_surat_masuk & $\begin{array}{l}\text { CREATE TABLE `pengelolaan_surat``data_surat_masuk` } \\
\text { (`id_dataSM`VARCHAR(10) NOT NULL, } \\
\text { `id_pendataan_surat`VARCHAR(10) NOT NULL, } \\
\text { ‘kode_surat`VARCHAR(20) NOT NULL, } \\
\text { ‘nomor_naskah_dinas`VARCHAR(20) NOT NULL, }\end{array}$ \\
\hline
\end{tabular}




\begin{tabular}{|l|l|}
\hline & `dari`VARCHAR(30) NOT NULL, `perihal` \\
& VARCHAR(50) NOT NULL, `isi_ringkasan`TEXT NOT \\
& NULL, ‘tgl_surat` DATE NOT NULL, `tgl_diterima` \\
& DATE NOT NULL, `lampiran`BLOB NOT NULL, \\
& `pengarahan_surat`VARCHAR(30) NOT NULL, \\
& `status_surat`VARCHAR(30) NOT NULL, PRIMARY \\
& KEY('id_dataSM`)) ENGINE = InnoDB;
\end{tabular}

Pada Tabel 2. Proses Create Tabel Database tidak memperlihatkan secara keseluruhan proses pembuatan table dalam database untuk lebih jelas dan rinci bisa dilihat pada Gambar 10. Perancangan Database Pengelolaan Surat.

Application Architecture, Target aplikasi arsitektur yang telah dirancang akan dijabarkan melalui tabel dibawah ini.

Tabel 3. Target aplikasi arsitektur.

\begin{tabular}{|c|c|c|c|}
\hline $\begin{array}{l}\text { Nama Sistem } \\
\text { Informasi }\end{array}$ & Fitur & Aktor & Fungsi \\
\hline \multirow[t]{6}{*}{$\begin{array}{l}\text { Sistem Informasi } \\
\text { Pengelolaan Surat }\end{array}$} & $\begin{array}{l}\text { Login } \\
\text { Admin }\end{array}$ & $\begin{array}{l}\text { Petugas } \\
\text { arsip }\end{array}$ & $\begin{array}{l}\text { Fungsinya dapat login ke sistem informasi } \\
\text { pengelolaan surat dengan memasukan } \\
\text { email dan password dengan benar. }\end{array}$ \\
\hline & Login User & Sekretaris & $\begin{array}{l}\text { Fungsinya dapat login ke sistem informasi } \\
\text { pengelolaan surat dengan memasukan } \\
\text { email dan password dengan benar }\end{array}$ \\
\hline & $\begin{array}{l}\text { Pendataan } \\
\text { Surat }\end{array}$ & $\begin{array}{l}\text { Petugas } \\
\text { arsip }\end{array}$ & $\begin{array}{l}\text { Fungsinya untuk melakukan pendataan } \\
\text { surat masuk dan surat keluar bisa tambah } \\
\text { surat, hapus surat, edit surat, cetak surat. }\end{array}$ \\
\hline & $\begin{array}{l}\text { Pengarahan } \\
\text { Surat }\end{array}$ & Sekretaris & $\begin{array}{l}\text { Fungsinya untuk membuat pengarahan / } \\
\text { disposisi surat pada saat ada transaksi surat } \\
\text { masuk dan surat keluar. }\end{array}$ \\
\hline & $\begin{array}{l}\text { Laporan } \\
\text { Surat }\end{array}$ & $\begin{array}{l}\text { Petugas } \\
\text { arsip }\end{array}$ & $\begin{array}{l}\text { Fungsinya untuk melakukan pelaporan } \\
\text { surat sesuai dengan jumlah data surat } \\
\text { masuk dan data surat keluar. }\end{array}$ \\
\hline & Status Surat & $\begin{array}{l}\text { Petugas } \\
\text { arsip }\end{array}$ & $\begin{array}{l}\text { Fungsinya digunakan untuk mengetahui } \\
\text { apakah surat masuk sudah diterima dan } \\
\text { untuk mengetahui apakah surat keluar } \\
\text { telah dikirim. }\end{array}$ \\
\hline
\end{tabular}

\section{Technology Architecture}

Tabel 4. Kebutuhan Teknologi Arsitektur Sistem Pengelolaan Surat

\begin{tabular}{|l|l|}
\hline \multicolumn{1}{|c|}{ Nama Sistem Informasi } & \multicolumn{1}{|c|}{ Kebutuhan Sistem } \\
\hline Sistem Informasi Pengelolaan Surat & Komputer Server \\
\cline { 2 - 2 } & Komputer client \\
\cline { 2 - 2 } & HUB \\
\cline { 2 - 2 } & Router \\
\cline { 2 - 2 } & Access point \\
\cline { 2 - 2 } & Koneksi internet \\
\cline { 2 - 2 } & Administrator database \\
\cline { 2 - 2 } & Printer and scanner \\
\hline
\end{tabular}




\section{Kerangka Kerja (Blueprint)}

Kerangka kerja (blueprint) dapat berupa sistem poin demi poin (desain) sebagai dasar untuk pembuatan pengaturan yang menggabungkan penetapan tujuan dan sasaran, perincian metodologi, pelaksanaan dan fokus program serta langkah-langkah atau pelaksanaan yang harus dilakukan oleh setiap unit tindakan di dalamnya. [12] Adapun hasil dari perancangan kerangka kerja (blueprint) pada pengelolaan surat akan digambarkan pada Gambar 16. Kerangka kerja pengelolaan surat.

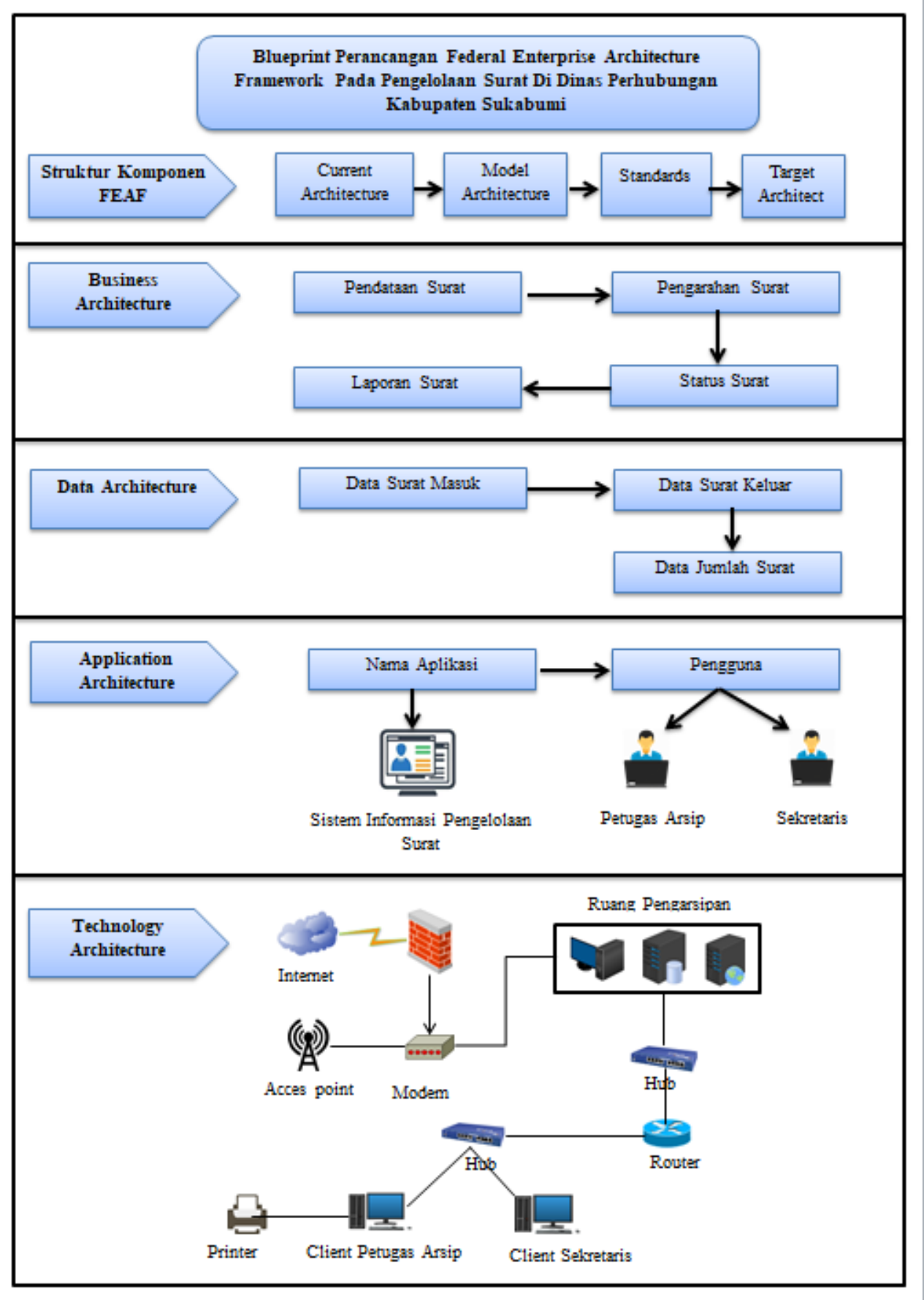

Gambar 16. Kerangka Kerja Pengelolaan Surat 


\section{Penutup}

Berdasarkan penelitian mengenai perancangan federal enterprise architecture framework pada pengelolaan surat yang ada di Dinas Perhubungan Kabupaten Sukabumi dapat disimpulkan bahwa FEAF memiliki 8 struktur komponen yang terdiri dari architecture drivers, current architecture, standards, transitional processes, architecture model, architecture segments, target architecture, dan strategic direction. Struktur komponen dalam penelitian ini menggunakan 4 struktur komponen FEAF yang digunakan berdasarkan kebutuhan, yaitu current architecture, model architecture, standards, dan target architecture. Dimana penelitian ini membahas mulai dari arsitektur yang sedang berjalan dan target arsitektur yang diinginkan, serta dapat membantu instansi dalam mewujudkan enterprise architecture untuk pengelolaan surat pada Dinas Perhubungan Kabupaten Sukabumi. Hasil luaran penelitian ini adalah kerangka kerja (blueprint) yang terdiri dari business architecture, data architecture, application architecture, dan technologi architecture yang menjelaskan mulai dari proses bisnis hingga teknologi yang dihasilkan. Kerangka kerja (blueprint) tersebut diharapkan menjadi kerangka acuan pengembangan sistem pengelolaan surat dan pedoman penerapannya di Dinas Perhubungan Kabupaten Sukabumi. Penelitian ini juga menjelaskan aktivitas yang digambarkan dengan perancangan use case diagram, activity diagram, class diagram atau database dan arsitektur jaringan.

\section{Daftar Pustaka}

[1] R. S. Naibaho, "Peranan Dan Perencanaan Teknologi Informasi Dalam Perusahaan," J. War., no. April, p. 4, 2017, [Online]. Available: https://media.neliti.com/media/publications/290731-peranan-dan-perencanaanteknologi-inform-ad00d595.pdf.

[2] M. Destiningrum and Q. J. Adrian, "Sistem Informasi Penjadwalan Dokter Berbassis Web Dengan Menggunakan Framework Codeigniter (Studi Kasus: Rumah Sakit Yukum Medical Centre),"J. Teknoinfo, vol. 11, no. 2, p. 30, 2017, doi: 10.33365/jti.v11i2.24.

[3] R. Irfanto and J. Fernandes Andry, "1 Perancangan Enterprise Architecture Menggunakan Zachman Framework (Studi Kasus: Pt.Vivamas Adipratama)," Peranc. Enterp. Archit. Menggunakan Zachman Fr, no. November, pp. 1-2, 2014.

[4] A. Susanto1, ni wayan Parwanti, and M. Lestari, "Sistem Informasi Pengelolaan Surat," J. Ris. dan Apl. Mhs. Inform., vol. 02, no. 01, pp. 8-14, 2003.

[5] N. Restiani, "Perancangan Blueprint Sistem Informasi Manajemen Arsip Berbasis Web dengan TOGAF ADM (Studi Kasus: Sekretariat IBI Kota Boyolali)," no. 1461700168, 2021.

[6] M. Hatta, M. M. Anwar, I. N. Diana, and M. H. Amarul M, "Perancangan Sistem Informasi Pengarsipan Dan Disposisi Surat Berbasis Web Dengan Menggunakan Framework Codeigniter," SCAN - J. Teknol. Inf. dan Komun., vol. 14, no. 2, 2019, doi: 10.33005/scan.v14i2.1481.

[7] S. Suhendri, "Perancangan Arsitektur Sistem Informasi Sekolah dengan The Open Group Architecture Framework(Togaf) (Studi Kasus: Pondok Pesantren Ar-Rahmat)," Infotech J., vol. 1, no. 2, p. 236609, 2015.

[8] Gao, "A Practical Guide to Federal Enterprise Architecture," Public Law, vol. 1, no. February 2001, p. 112, 2001, [Online]. Available: http://www.citeulike.org/group/15536/article/9666776.

[9] F. Lestiawan and A. B. Johan, "Penerapan Metode Pembelajaran Example Nonexample Untuk Meningkatkan Keaktifan Dan Hasil Belajar Dasar-Dasar Pemesinan," Taman Vokasi, vol. 6, no. 1, p. 98, 2018, doi: 10.30738/jtvok.v6i1.2866.

[10] D. Prasanti, "Penggunaan Media Komunikasi Bagi Remaja Perempuan Dalam Pencarian Informasi Kesehatan," LONTAR J. Ilmu Komun., vol. 6, no. 1, pp. 13-21, 2018, doi: 10.30656/lontar.v6i1.645. 
@is The Best : Accounting Information Systems and Information Technology Business Enterprise ISSN: 2252-9853 (Print) | ISSN: 2656-808X (Online)

[11] P. Soepomo, "Penerapan Sistem Keamanan Honeypot dan Ids pada Jaringan Nirkabel (Hotspot)," JSTIE Jurnal Sarj. Tek. Inform., vol. 1, no. 1, pp. 111-118, 2013, doi: 10.12928/jstie.v1i1.2512.

[12] R. R. Rerung, "Perencanaan Arsitektur Sistem Informasi Dinas Pariwisata Menggunakan Model Eap," Simetris J. Tek. Mesin, Elektro dan Ilmu Komput., vol. 8, no. 1, pp. 327-338, 2017, doi: $10.24176 /$ simet.v8i1.997. 